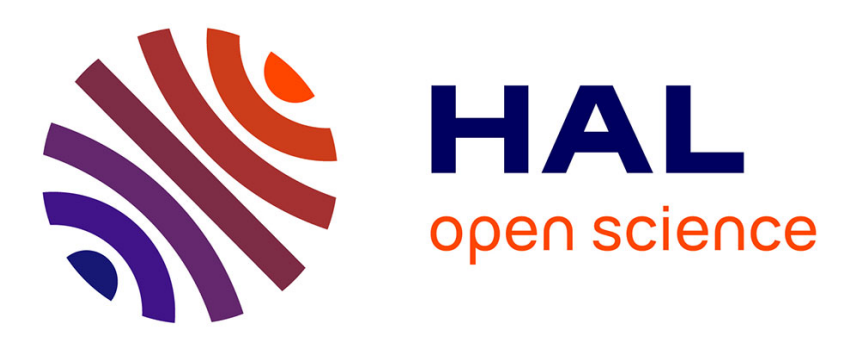

\title{
Faeces of generalist predators as 'biodiversity capsules': A new tool for biodiversity assessment in remote and inaccessible habitats
}

Stéphane Boyer, Robert H Cruickshank, Stephen Wratten

\section{- To cite this version:}

Stéphane Boyer, Robert H Cruickshank, Stephen Wratten. Faeces of generalist predators as 'biodiversity capsules': A new tool for biodiversity assessment in remote and inaccessible habitats. Food Webs, 2015, 3, pp.1-6. 10.1016/j.fooweb.2015.02.001 . hal-02163774

\author{
HAL Id: hal-02163774 \\ https://hal.science/hal-02163774
}

Submitted on 2 Oct 2019

HAL is a multi-disciplinary open access archive for the deposit and dissemination of scientific research documents, whether they are published or not. The documents may come from teaching and research institutions in France or abroad, or from public or private research centers.
L'archive ouverte pluridisciplinaire HAL, est destinée au dépôt et à la diffusion de documents scientifiques de niveau recherche, publiés ou non, émanant des établissements d'enseignement et de recherche français ou étrangers, des laboratoires publics ou privés. 
Title: Faeces of generalist predators as 'biodiversity capsules': a new tool for biodiversity assessment in remote and inaccessible habitats

\section{Running Head: Generalist predator faeces as 'biodiversity capsules'}

\section{Authors: Stéphane Boyer1,2,3, Robert H. Cruickshank², Stephen D. Wratten ${ }^{3}$}

${ }^{1}$ Department of Natural Sciences, Faculty of Social and Health Sciences, Unitec Institute of Technology, 139 Carrington Road, Mt Albert, Auckland 1025, New Zealand

2 Department of Ecology, Faculty of Agriculture and Life Sciences, PO Box 85084, Lincoln University, Christchurch 7647, New Zealand.

${ }^{3}$ Bio-Protection Research Centre, PO Box 85084, Lincoln University, Christchurch 7647, New Zealand.

Corresponding author: Stephane Boyer. Department of Natural Sciences, Faculty of Social and Health Sciences, Unitec Institute of Technology, 139 Carrington Road, Mt Albert, Auckland 1025, New Zealand.Email: Stéphane.Boyer@gmail.com

\footnotetext{
Abstract

Molecular methods are increasingly used to identify prey DNA in predators' faeces to describe diet composition. However, such analysis can reveal much more ecological information. If faeces are regarded as 'biodiversity capsules', they can help describe and
} 
quantify ecological communities by containing a representative sample of the prey species occurring in the foraging area of a given predator. Here we propose to analyse these 'capsules' and infer the occurrence, distribution and minimum abundance estimate of prey communities. This novel approach goes beyond the detection of 'targeted' prey groups to inform dietary studies of predators. It is particularly suited to the study of prey communities that are difficult to sample with traditional methods because they are very small, rare and/or live in remote or inaccessible habitats. Such communities include invertebrates inhabiting the soil, deep-sea species, and small, rare flying insects. The proposed approach has the potential to inform the topical issue of biodiversity assessment and provides a new framework for the discovery of species with minimum interference to ecosystems and without the need for extensive trapping, which can be labour intensive and could kill many individuals of non-target species. Rigorous testing of this approach, and in particular direct comparison with traditional sampling methods is required to fully demonstrate its efficacy.

Keywords: next-generation sequencing; DNA barcoding; eDNA; optimal foraging theory; generalist predators; molecular diet analyses; biodiversity discovery

\section{Introduction}

In the past decade molecular techniques have been increasingly used to detect prey DNA and identify predated species using gut contents or faecal samples from predators (Symondson, 2002; King et al., 2008; Symondson \& Harwood, 2014). For predators of no 
conservation concern, individuals can be sacrificed and prey tissue in the guts can be isolated and used for visual or DNA analysis (Carreon-Martinez et al., 2011). However, it is not always possible to detect and isolate such tissues from the gut contents of predators. This is the case for many predatory species, including those feeding on prey which are mainly soft-bodied such as the juvenile stages of many holometabolous insects (45\% of all animal species), molluscs (85,000 known species), earthworms (up to $98 \%$ of all animal biomass in forest ecosystems (Brockie \& Moeed, 1986)), etc. Similarly, the detection of prey tissue samples is not possible in the gut of liquid-feeding predators such as spiders, true bugs (Hemiptera) and mites. The analysis of faecal DNA samples is more widely applicable than morphological studies but suffers from particular technical limitations. One major issue has been the presence of mixed DNA from several prey species in one faecal sample, which causes standard (Sanger dideoxy) DNA sequencing to fail (Boyer et al., 2011). Although this is not an issue for species with highly specialised diets (Rougerie et al., 2011), this is particularly limiting for generalist predators that feed on a variety of prey species. Until recently, such mixed DNA samples could be analysed only after the development of large panels of species-specific primers (Jarman et al., 2004) used in complex multiplex PCRs (Harper et al., 2005; King et al., 2011) or cloning analyses (Zeale et al., 2011).

By combining (i) high-throughput next-generation sequencing (e.g. Margulies et al., 2005), (ii) the use of individual molecular tags (Parameswaran et al., 2007), and (iii) new bioinformatic tools for the selection of mini-barcodes (e.g. Brown et al., 2012), it is now possible to sequence mixed DNA samples and identify every species present in the diet of a given predator (Boyer et al., 2012). Accurate identification at the species level remains dependent on the comprehensiveness of the available DNA sequence reference 
libraries and the capacity of group-specific primers to amplify a mixture of DNA. Beyond the implications for conservation biology, particularly in endangered predatory species for which feeding behaviour is difficult to observe, combining these recent molecular techniques provides a new tool for rapid and easy assessment of animal communities through predator faeces. The latter can therefore be regarded as 'biodiversity capsules' possibly containing a representative sample of prey species occurring in the predator's foraging area. Although other sources of environmental DNA have been used for such purpose (Box 1), faecal samples have rarely been considered in such studies.

\section{Estimates of prey species diversity using predator faecal samples}

Developing novel tools to better assess biodiversity is crucial to the discovery of new and cryptic species, the study of rare and poorly known taxa, and the monitoring and conservation of endangered and declining species, all of which are key to better understanding and addressing the current biodiversity crisis (Barnosky et al., 2011). With new species documented every day (Zhang, 2011), many may disappear even before they are discovered (Barnosky et al., 2011). Some are very difficult to detect or study because they are very small and/or at low density in remote or impenetrable habitats such as those designated as main biotic frontiers (André et al. 1994). This includes, but is not limited to, soil invertebrates, species inhabiting deep seas and small and rare flying insects. Generalist predators feeding on such species essentially harvest their DNA (Fig. 1), which can then be readily retrieved from faecal samples and used as proxy for prey species inventories and ecosystem monitoring programmes (Jarman et al., 2013). With a comprehensive network of known collection sites and basic knowledge 
about the predator's dispersal abilities, prey occurrence data could also be used to draw distribution maps. This may require cautious correction for potential methodological biases such as prey preferences, detection limit, PCR bias etc. (see section Strategies and limitations).

Because predators have evolved to find their prey efficiently, their faeces can contain prey species that would have been difficult to collect using conventional sampling methods. For example, Bohmann et al. (2011) analysed 89 faecal pellets to assess the diet of two African bat species (Chiroptera:Molossidae) and found DNA from 236 different prey taxa (molecular operational taxonomic units, MOTUs). Almost $80 \%$ of these were detected in only one guano pellet. In another study by Burgar et al. (2014) 190 MOTUs were detected from 63 faecal samples produced by three different bat species, but only $20 \%$ of these MOTUs could be assigned to known species. Although the authors did not identify taxa at the species level, it is likely that many of these MOTUs were rare or even unknown species and they would have been difficult to collect and identify using conventional sampling methods without considerable trapping effort. Similar patterns have been observed for terrestrial predators that feed on marine prey but produce faeces on land. In 2007, Deagle et al. (Deagle et al., 2007) studied the diet of Macaroni penguins (Sphenisciformes:Spheniscidae) using faecal samples. Among the six species of fish for which $16 \mathrm{~S}$ mtDNA sequences were retrieved there was one that did not match any sequence in GenBank and was about 20\% divergent from any other fish species for which $16 \mathrm{~S}$ sequences were available. This species could not be classified further than to the superorder of Acanthopterygii. Despite the great interest and comprehensive body of knowledge existing for this group, and very high rates of DNA sequencing in the recent years (Ward et al., 2009; Becker et al., 2011; Trivedi et al., 
2015), the unidentified species still displayed 16\% divergence from any other fish species sequenced to date. These sequences are therefore likely to correspond to yet undescribed species, which illustrates the potential of faecal samples to inform future sampling efforts and support the discovery of new species. Indeed, the discovery of new DNA sequences that do not match any known species gives us a clue with regards to the distribution of these potential new species. If they are only found in faeces collected at a certain time of the year or at a certain location, this gives indications of where and when to focus sampling efforts to collect specimens necessary for formal species discovery. Another similar example is given by Deagle et al. (Deagle et al., 2009) who analysed the diet of Australian fur seals (Carnivora:Otariidae) and found 15 fish species (27\% of the predated species) for which classification could be determined only to family (1), order (2), superorder (2) or infraclass (10) level. Even sampling programmes that appear to be comprehensive can still be incomplete. Despite sampling $\sim 2,400 \mathrm{~kg}$ of soil and sorting 1,500 earthworm individuals to inventory the species present in the vicinity of the Stockton mine in New Zealand, Boyer et al. (2013) missed three species of earthworms that were predated by the carnivorous land snail Powelliphanta augusta (Gastropoda:Rhytididae) in this area and whose DNA was amplified from the snails' faeces. These three earthworm species were regarded by the authors as putative deep burrowers that can live several meters below the soil surface (Sims \& Gerard, 1985). Such species may not be rare but simply very difficult to collect using traditional methods.

\section{Estimates of prey species abundance using predator faecal samples}


Optimal foraging theory (MacArthur \& Pianka, 1966), predicts that generalist predators select their prey in relation to the energetic benefit the latter represent and the energetic costs required to predate them (Doniol-Valcroze et al., 2011). Prey species of comparable size, physiology and behaviour are therefore likely to be predated in relation to their distribution and abundance. Direct quantification of prey consumption using amplicon numbers is not recommended because of potential differences in digestibility, individual size and amounts of mitochondrial DNA per gram of tissues from different prey species (Deagle et al., 2010). A few studies have shown that the proportion of prey species' DNA retrieved from predator faecal samples and amplified by qPCR can be somewhat representative of the proportion of biomass eaten (Deagle \& Tollit, 2007; Bowles et al., 2011). And these sequence counts have been used as semiquantitative measures of the biomass of prey eaten (Deagle et al., 2009). However, a more recent study has shown that in most cases, additional information on prey physiology and prey tissue digestibility is required to correct for biological biases, and multiple sequencing runs, or the inclusion of controls (i.e. DNA mixtures of known proportions of different prey species), may be necessary to account for technical biases (Deagle et al., 2013). Therefore, the relative contribution of each predated species to the diet is typically estimated by comparing the occurrence of each prey species in the faeces of several individuals of a given predator population (Bowser et al., 2013; Waterhouse et al., 2014).

The opportunity to estimate abundance of predated species is unique to predators because the presence of DNA from one prey species in one faecal sample means that at least one individual prey item was killed by one individual predator. Although recent studies have applied similar concepts for the detection of particular predated species 
using gut or faecal DNA in parasites (Schnell et al., 2012), herbivores (Hibert et al., 2013) or detritivores (Calvignac-Spencer et al., 2013b), the estimation of abundance is much more difficult in these cases because many individuals often feed on the same individual prey (or host) without necessarily causing its death. This means that although presence or absence of the prey (or host) species can be accurately estimated (Calvignac-Spencer et al., 2013a), the occurrence of prey DNA in the faeces of parasites, herbivores or detritivores (i.e. the proportion of those tested positive for a particular prey/host species) cannot be related to the abundance of prey (or host) individuals. Those predators which completely consume their prey, are much more informative in this context, particularly if faecal samples can be collected in a way that ensures independence (i.e. no two faecal samples are collected from the same individual). In such independent samples, the occurrence of a prey species' DNA in one faecal sample corresponds to at least one individual prey item eaten. This is possible for example when faecal samples are collected from an animal's burrow or nest (see Table 1 for examples). Such predators can therefore provide minimum estimates of prey abundance, which unlocks wider applications in environmental science research (Lodge et al., 2012).

\section{Strategies and limitations}

The biodiversity capsule approach proposed here is based on similar tools and suffers from similar limitations to molecular diet analyses. However, the aim and scope are different and three contrasting strategies can be identified (Fig. 2). 
Strategy 1 uses species-specific primers to detect the DNA of only one or a few prey species. This allows only detection of the target prey species and the determination of a trophic relationship between two species. This can be useful when the prey species is of particular interest, e.g. a pest species for which potential biocontrol agents are investigated (e.g. Lundgren \& Fergen, 2014). Any DNA region that is specific to the 'target' prey species can be used for this strategy.

Strategy 2 uses group-specific primers to amplify DNA from a group of taxonomically related species. This strategy can provide diet composition or an inventory of predated species and under certain circumstances, can be used to estimate the relative quantitative contribution of each prey species to the diet or an estimate of the relative abundance of each predated species in the environment. This strategy has been applied using a variety of molecular markers, especially those in which the design of groupspecific primers is made easy by the presence of stretches of conserved DNA and stretches of more variable DNA (e.g. 16S) as detailed by Deagle et al. (Deagle et al., 2009). This strategy can also be used for biodiversity assessments, with the limitation that only a subset of prey species can be detected (those for which DNA is compatible with the group-specific primers).

Strategy 3 uses very generic (sometimes called 'universal') primers to amplify all predated species, irrespective of their taxonomic group. This strategy is rarely applied to molecular diet analysis. It requires the addition of a blocking primer to ensure that the DNA of the predator is not amplified and does not interfere with that of predated species (Vestheim \& Jarman, 2008). This strategy is ideal for biodiversity inventories. However, to guarantee prey identification at the species level a comprehensive DNA 
library for the chosen molecular marker is required. Currently, such a library exists only for the DNA barcoding region of the COI gene with more than 3.7 million sequences available in the barcode of life database (BOLD) and 154,085 animal species formally barcoded (http://www.barcodinglife.com). However, for a number of communities, particularly those that have been poorly studied, the current BOLD database will not support complete resolution at the species level. For taxonomic groups that are largely unknown, there is a risk of overestimating or underestimating biodiversity in situations of exceptionally high intraspecific variation or exceptionally low interspecific divergence (Shearer \& Coffroth, 2008). Non-identifiable sequences are still informative because the broad coverage of the existing COI library allows classification, at least to a higher taxonomic level, of species that have not yet been barcoded. The detection of such species in faecal samples is valuable to pinpoint where and when specimen sampling is likely to help discovering putative new species. The BOLD database is growing at an increasing rate and its limitations are expected to lessen with time. COI, or a mini-barcode internal to COI (e.g. Hajibabaei et al., 2006), is therefore the ideal candidate for the biodiversity capsule approach. Other possible sources of biodiversity overestimation include secondary prey detection where DNA adheres to or is retained within the gut-contents of the predated items (Sheppard et al., 2005) and amplification of nuclear mitochondrial pseudogenes (NUMTs) (Dunshea et al., 2008; Moulton et al., 2010; Zeale et al., 2011). However, NUMTs and secondary prey DNA are probably less likely to be amplified from faecal samples due to lower copy number and higher degradation.

The proposed approach is likely to be limited by the range of prey species predated by the chosen predator. Because no predator is entirely generalist, basic knowledge about 
prey selection or preferences and predator movements is required. When broad prey coverage is intended and several generalist predators co-occur, a multi-species approach may be necessary because generalist predators may partition resources in non-obvious ways (Emrich et al., 2014).

\section{Conclusions}

Predator faeces comprise immobile, non-invasive and concentrated environmental DNA samples that can be rapidly, easily and inexpensively collected (Bohmann et al., 2011). In the case of generalist predators, faeces can be regarded as 'biodiversity capsules' possibly containing a representative DNA sample of prey species occurring in the predator's foraging area. Molecular analyses of these capsules are likely to provide valuable information about prey occurrence, distribution, and in some cases an approximate estimation of relative prey abundance. Potential biases include variations in prey size, behaviour and palatability, which are likely to directly influence predation as well as predator behaviour and preferences. However, similar biases also exist in traditional sampling methods (e.g. Halsall \& Wratten, 1988).

The biodiversity capsules approach therefore goes beyond establishing predator-prey relationships to producing faunal inventories, significantly improving on what is possible with current, more orthodox methods. For this purpose, targeted predators might not be chosen on the basis of their conservation status but rather because of particular interests in the prey communities on which they feed (see Table 1 for examples). Despite their potential, faecal DNA samples have not yet been used for such biodiversity assessments. Such analyses are applicable for virtually any prey species, including soft-bodied organisms. This approach is also relevant to a wide range of 
predators (including liquid feeders) and is particularly suited to (i) prey species that are difficult to sample because they mostly live deep in soil but for which a generalist predator deposits faecal material on the surface (Boyer et al., 2013); (ii) prey species that are difficult to sample because they live in aquatic environment, particularly in the open ocean or below the pelagic zone but for which a generalist predator deposits faecal material on land (Deagle et al., 2009); (iii) prey species that are difficult to sample because they are widely dispersed at a low density over large areas but for which a generalist predator deposits faecal material in an aggregated way (Bowles et al., 2011).

The use of generalist predator faeces as biodiversity capsules is therefore promising for biodiversity sampling in remote regions and inaccessible habitats, which are often characterised by poorly known local fauna (Hajibabaei et al., 2011). It also allows detecting and monitoring of cryptic species, including 'short-range endemics', to assess the potential impact of proposed major development projects (Harvey et al., 2011). This approach causes minimum interference to native ecosystems and does not require extensive trapping, which can be labour intensive and could kill many individuals of non-target species. Rigorous testing of this approach, and in particular direct comparison with comprehensive sampling based on traditional methods, would be required to fully demonstrate its efficiency. By applying the biodiversity capsules approach to prey communities and geographical areas for which traditionally sampled biodiversity inventories exist, it will be possible to quantify the limitations and potential biases discussed above. 


\section{Acknowledgements}

Stephane Boyer's work has been funded by Solid Energy New Zealand Limited, Rio Tinto Limited and the Bio-Protection Research Centre. We also received support from the Department of Ecology at Lincoln University. The funders had no role in study design, data collection and interpretation, or the decision to submit the work for publication.

\section{Literature cited}

Andersen K., Bird K.L., Rasmussen M., Haile J., Breuning-Madsen H., Kjaer K.H., Orlando L., Gilbert M.T.P., \& Willerslev E. (2012) Meta-barcoding of “dirt” DNA from soil reflects vertebrate biodiversity. Molecular Ecology, 21, 1966-79.

Barnosky A.D., Ferrer E.A., Lindsey E.L., Maguire K.C., Marshall C., Matzke N., McGuire J.L., Mersey B., Quental T.B., Swartz B., Tomiya S., \& Wogan G.O.U. (2011) Has the Earth's sixth mass extinction already arrived? Nature, 471, 51-57.

Becker S., Hanner R., \& Steinke D. (2011) Five years of FISH-BOL: brief status report. Mitochondrial DNA, 22 Suppl 1, 3-9.

Bienert F., De Danieli S., Miquel C., Coissac E., Poillot C., Brun J.-J., \& Taberlet P. (2012) Tracking earthworm communities from soil DNA. Molecular Ecology, 21, 2017-30.

Bohmann K., Monadjem A., Lehmkuhl Noer C., Rasmussen M., Zeale M.R.K., Clare E., Jones G., Willerslev E., \& Gilbert M.T.P. (2011) Molecular Diet Analysis of Two African Free-Tailed Bats (Molossidae) Using High Throughput Sequencing. PLoS ONE, 6, e21441.

Bowles E., Schulte P.M., Tollit D.J., Deagle B.E., \& Trites A.W. (2011) Proportion of prey consumed can be determined from faecal DNA using real-time PCR. Molecular Ecology Resources, 11, 530-540.

Bowser a. K., Diamond A.W., \& Addison J. a. (2013) From puffins to plankton: A DNAbased analysis of a seabird food chain in the Northern Gulf of Maine. PLoS ONE, 8, $1-16$.

Boyer S., Brown S.D.J., Collins R.A., Cruickshank R.H., Lefort M.-C.D., Malumbres-Olarte J., $\&$ Wratten S.D. (2012) Sliding window analyses for optimal selection of mini- 
barcodes, and application to 454- pyrosequencing for specimen identification from degraded DNA. PLoS ONE, 7, e38215.

Boyer S., Wratten S.D., Holyoake A., Abdelkrim J., \& Cruickshank R.H. (2013) Using NextGeneration Sequencing to Analyse the Diet of a Highly Endangered Land Snail (Powelliphanta augusta) Feeding on Endemic Earthworms. PLoS ONE, 8, e75962.

Boyer S., Yeates G.W., Wratten S.D., Holyoake A., \& Cruickshank R.H. (2011) Molecular and morphological analyses of faeces to investigate the diet of earthworm predators: example of a carnivorous landsnail endemic to New Zealand. Pedobiologia, 54S, S153-S158.

Brockie R.E. \& Moeed A. (1986) Animal biomass in a New Zealand forest compared with other parts of the world. Oecologia, 70, 24-34.

Brown S.D.J., Collins R. a, Boyer S., Lefort M.-C., Malumbres-Olarte J., Vink C.J., \& Cruickshank R.H. (2012) Spider: An R package for the analysis of species identity and evolution, with particular reference to DNA barcoding. Molecular Ecology Resources, 12, 562-565.

Burgar J.M., Murray D.C., Craig M.D., Haile J., Houston J., Stokes V., \& Bunce M. (2014) Who's for dinner? High-throughput sequencing reveals bat dietary differentiation in a biodiversity hotspot where prey taxonomy is largely undescribed. Molecular Ecology, 23, 3605-3617.

Calvignac-Spencer S., Leendertz F.H., Gilbert M.T.P., \& Schubert G. (2013a) An invertebrate stomach's view on vertebrate ecology: Certain invertebrates could be used as "vertebrate samplers" and deliver DNA-based information on many aspects of vertebrate ecology. BioEssays, .

Calvignac-Spencer S., Merkel K., Kutzner N., Kühl H., Boesch C., Kappeler P.M., Metzger S., Schubert G., \& Leendertz F.H. (2013b) Carrion fly-derived DNA as a tool for comprehensive and cost-effective assessment of mammalian biodiversity. Molecular Ecology, 22, 915-24.

Carreon-Martinez L., Johnson T.B., Ludsin S. a, \& Heath D.D. (2011) Utilization of stomach content DNA to determine diet diversity in piscivorous fishes. Journal of Fish Biology, 78, 1170-82.

Collins R. a., Armstrong K.F., Holyoake A.J., \& Keeling S. (2012) Something in the water: biosecurity monitoring of ornamental fish imports using environmental DNA. Biological Invasions, 15, 1209-1215.

Deagle B., Gales N., \& Evans K. (2007) Studying seabird diet through genetic analysis of faeces: a case study on macaroni penguins (Eudyptes chrysolophus). PLOS ONE, 2, e831. 
Deagle B. \& Tollit D. (2007) Quantitative analysis of prey DNA in pinniped faeces: potential to estimate diet composition? Conservation Genetics, 8, 743-747.

Deagle B.E., Chiaradia A., McInnes J., \& Jarman S.N. (2010) Pyrosequencing faecal DNA to determine diet of little penguins: is what goes in what comes out? Conservation Genetics, 11, 2039-2048.

Deagle B.E., Kirkwood R., \& Jarman S.N. (2009) Analysis of Australian fur seal diet by pyrosequencing prey DNA in faeces. Molecular Ecology, 18, 2022-2038.

Deagle B.E., Thomas A.C., Shaffer A.K., Trites A.W., \& Jarman S.N. (2013) Quantifying sequence proportions in a DNA-based diet study using Ion Torrent amplicon sequencing: which counts count? Molecular Ecology Resources, 13, 620-633.

Dejean T., Valentini A., Duparc A., Pellier-Cuit S., Pompanon F., Taberlet P., \& Miaud C. (2011) Persistence of environmental DNA in freshwater ecosystems. PLoS ONE, 6, e23398.

Doniol-Valcroze T., Lesage V., Giard J., \& Michaud R. (2011) Optimal foraging theory predicts diving and feeding strategies of the largest marine predator. Behavioral Ecology, 22, 880-888.

Dunshea G., Barros N.B., Wells R.S., Gales N.J., Hindell M. a, \& Jarman S.N. (2008) Pseudogenes and DNA-based diet analyses: a cautionary tale from a relatively well sampled predator-prey system. Bulletin of Entomological Research, 98, 239-48.

Emrich M. a., Clare E.L., Symondson W.O.C., Koenig S.E., \& Fenton M.B. (2014) Resource partitioning by insectivorous bats in Jamaica. Molecular Ecology, 23, 3648-3656.

Ficetola G.F., Miaud C., Pompanon F., \& Taberlet P. (2008) Species detection using environmental DNA from water samples. Biology Letters, 4, 423-5.

Goldberg C.S., Pilliod D.S., Arkle R.S., \& Waits L.P. (2011) Molecular detection of vertebrates in stream water: a demonstration using rocky mountain tailed frogs and idaho giant salamanders. PLoS ONE, 6, e22746.

Hadly E. \& Tuinen M. Van (2003) Ancient DNA Evidence of Prolonged Population Persistence with Negligible Genetic Diversity in an Endemic Tuco-Tuco (Ctenomys sociabilis). Journal of Mammalogy, 84, 403-417.

Hajibabaei M., Shokralla S., Zhou X., Singer G.A.C., \& Baird D.J. (2011) Environmental Barcoding: A Next-Generation Sequencing Approach for Biomonitoring Applications Using River Benthos. PLoS ONE, 6, e17497.

Hajibabaei M., Smith M.A., Janzen D.H., Rodriguez J.J., Whitfield J.B., \& Hebert P.D.N. (2006) A minimalist barcode can identify a specimen whose DNA is degraded. Molecular Ecology Notes, 6, 959-964. 
Halsall N.B. \& Wratten S.D. (1988) The efficiency of pitfall trapping for polyphagous predatory Carabidae. Ecological Entomology, 13, 293-299.

Harper G.L., King R.A., Dodd C., Harwood J.D., Glen D., Bruford M.W., \& Symondson W.O.C. (2005) Rapid screening of invertebrate predators for multiple prey DNA targets. Molecular Ecology, 14, 819-827.

Harvey M.S., Rix M.G., Framenau V.W., Hamilton Z.R., Johnson M.S., Teale R.J., Humphreys G., \& Humphreys W.F. (2011) Protecting the innocent: studying short-range endemic taxa enhances conservation outcomes. Invertebrate Systematics, 25, 1-10.

Hibert F., Taberlet P., Chave J., Scotti-Saintagne C., Sabatier D., \& Richard-Hansen C. (2013) Unveiling the diet of elusive rainforest herbivores in next generation sequencing era? the tapir as a case study. PLOS ONE, 8, e60799.

Jarman S.N., Deagle B.E., \& Gales N.J. (2004) Group-specific polymerase chain reaction for DNA-based analysis of species diversity and identity in dietary samples. Molecular Ecology, 13, 1313-1322.

Jarman S.N., McInnes J.C., Faux C., Polanowski A.M., Marthick J., Deagle B.E., Southwell C., \& Emmerson L. (2013) Adélie penguin population diet monitoring by analysis of food DNA in scats. PLoS ONE, 8, e82227.

King R.A., Moreno-Ripoll R., Agustí N., Shayler S.P., Bell J.R., Bohan D. a, Symondson W.O.C., \& Agusti N. (2011) Multiplex reactions for the molecular detection of predation on pest and nonpest invertebrates in agroecosystems. Molecular Ecology Resources, 11, 370-373.

King R.A., Read D.S., Traugott M., \& Symondson W.O.C. (2008) Molecular analysis of predation: a review of best practice for DNA-based approaches. Molecular Ecology, 17, 947-963.

Lefort M.-C., Boyer S., Worner S.P., \& Armstrong K. (2012) Noninvasive molecular methods to identify live scarab larvae: an example of sympatric pest and nonpest species in New Zealand. Molecular Ecology Resources, 12, 389-395.

Lodge D.M., Turner C.R., Jerde C.L., Barnes M. a, Chadderton L., Egan S.P., Feder J.L., Mahon A.R., \& Pfrender M.E. (2012) Conservation in a cup of water: estimating biodiversity and population abundance from environmental DNA. Molecular Ecology, 21, 2555-8.

Lundgren J.G. \& Fergen J.K. (2014) Predator community structure and trophic linkage strength to a focal prey. Molecular Ecology, 23, 3790-3798.

MacArthur R. \& Pianka E. (1966) on optimal use of a patchy environment. American Naturalist, 100, 603-609. 
Margulies M., Egholm M., Altman W.E., Attiya S., Bader J.S., Bemben L.A., Berka J., Braverman M.S., Chen Y.J., Chen Z.T., Dewell S.B., Du L., Fierro J.M., Gomes X. V, Godwin B.C., He W., Helgesen S., Ho C.H., Irzyk G.P., Jando S.C., Alenquer M.L.I., Jarvie T.P., Jirage K.B., Kim J.B., Knight J.R., Lanza J.R., Leamon J.H., Lefkowitz S.M., Lei M., Li J., Lohman K.L., Lu H., Makhijani V.B., McDade K.E., McKenna M.P., Myers E.W., Nickerson E., Nobile J.R., Plant R., Puc B.P., Ronan M.T., Roth G.T., Sarkis G.J., Simons J.F., Simpson J.W., Srinivasan M., Tartaro K.R., Tomasz A., Vogt K.A., Volkmer G.A., Wang S.H., Wang Y., Weiner M.P., Yu P.G., Begley R.F., \& Rothberg J.M. (2005) Genome sequencing in microfabricated high-density picolitre reactors. Nature, 437, 376-380.

Minamiya Y., Ohga K., Hayakawa H., Ito K., \& Fukuda T. (2011) Coelomic fluid: a noninvasive source of DNA in earthworms. Molecular Ecology Resources, 11, 645-9.

Moulton M.J., Song H., \& Whiting M.F. (2010) Assessing the effects of primer specificity on eliminating numt coamplification in DNA barcoding: a case study from Orthoptera (Arthropoda: Insecta). Molecular Ecology Resources, 10, 615-27.

Parameswaran P., Jalili R., Tao L., Shokralla S., Gharizadeh B., Ronaghi M., \& Fire A.Z. (2007) A pyrosequencing-tailored nucleotide barcode design unveils opportunities for large-scale sample multiplexing. Nucleic Acids Research, 35, 1-9.

Pawlowski J., Christen R., Lecroq B., Bachar D., Shahbazkia H.R., Amaral-Zettler L., \& Guillou L. (2011) Eukaryotic richness in the abyss: insights from pyrotag sequencing. PLOS ONE, 6, e18169.

Poulakakis N. (2005) Isolation and amplification of shrew DNA from barn owl pellets. Biological Journal of the Linnean Society, 85, 331-340.

Rougerie R., Smith M.A., Fernandez-Triana J., Lopez-Vaamonde C., Ratnasingham S., \& Hebert P.D.N. (2011) Molecular analysis of parasitoid linkages (MAPL): gut contents of adult parasitoid wasps reveal larval host. Molecular Ecology, 20, 179-86.

Schnell I.B., Thomsen P.F., Wilkinson N., Rasmussen M., Jensen L.R.D.D., Willerslev E., Bertelsen M.F., Gilbert M.T.P., \& Thomas M.P. (2012) Screening mammal biodiversity using DNA from leeches. Current Biology, 22, R262-R263.

Shearer T.L. \& Coffroth M. a (2008) Barcoding corals: limited by interspecific divergence, not intraspecific variation. Molecular Ecology Resources, 8, 247-255.

Sheppard S.K., Bell J., Sunderland K.D., Fenlon J., Skervin D., \& Symondson W.O.C. (2005) Detection of secondary predation by PCR analyses of the gut contents of invertebrate generalist predators. Molecular Ecology, 14, 4461-8.

Sims R.W. \& Gerard B.M. (1985) Earthworms: Keys and Notes for the Identification and Study of the Species. Linnean Society of London, Estuarine and Brackish-Water Sciences Association, 
Symondson W.O.C. (2002) Molecular identification of prey in predator diets. Molecular Ecology, 11, 627-641.

Symondson W.O.C. \& Harwood J.D. (2014) Special issue on molecular detection of trophic interactions: unpicking the tangled bank. Introduction. Molecular Ecology, 23, 3601-4.

Taberlet P. \& Fumagalli L. (1996) Owl pellets as a source of DNA for genetic studies of small mammals. Molecular Ecology, 5, 301-5.

Taberlet P., Prud'Homme S.M., Campione E., Roy J., Miquel C., Shehzad W., Gielly L., Rioux D., Choler P., Clément J.-C., Melodelima C., Pompanon F., \& Coissac E. (2012) Soil sampling and isolation of extracellular DNA from large amount of starting material suitable for metabarcoding studies. Molecular Ecology, 21, 1816-20.

Thomsen P., Kielgast J., \& Iversen L. (2012) Monitoring endangered freshwater biodiversity using environmental DNA. Molecular Ecology, 21, 2565-73.

Trivedi S., Aloufi A.A., Ansari A.A., \& Ghosh S.K. (2015) Role of DNA Barcoding in Marine Biodiversity Assessment and Conservation: An update. Saudi Journal of Biological Sciences, .

Vestheim H. \& Jarman S.N. (2008) Blocking primers to enhance PCR amplification of rare sequences in mixed samples - a case study on prey DNA in Antarctic krill stomachs. Frontiers in Zoology, 5, 12.

Ward R.D., Hanner R., \& Hebert P.D.N. (2009) The campaign to DNA barcode all fishes, FISH-BOL. Journal of Fish Biology, 74, 329-56.

Waterhouse B.R., Boyer S., \& Wratten S.D. (2014) Pyrosequencing of prey DNA in faeces of carnivorous land snails to facilitate ecological restoration and relocation programmes. Oecologia, 175, 737-46.

Zeale M.R.K., Butlin R.K., Barker G.L.A., Lees D.C., \& Jones G. (2011) Taxon-specific PCR for DNA barcoding arthropod prey in bat faeces. Molecular Ecology Resources, 11, 236-244.

Zhang Z. (2011) Accelerating biodiversity descriptions and transforming taxonomic publishing: the first decade of Zootaxa. Zootaxa, 2896, 1-7.

Zinger L., Gobet A., \& Pommier T. (2012) Two decades of describing the unseen majority of aquatic microbial diversity. Molecular Ecology, 21, 1878-96. 


\section{Boxes, tables and IFgures}

Box 1: Assessing biodiversity using other sources of environmental DNA

Environmental samples are often easier to collect than are individuals themselves. This is not limited to faecal samples; other sources of environmental DNA have also been used to assess biodiversity, with successes and limitations. For example, environmental DNA from water samples has been used to assess vertebrate and invertebrate biodiversity in stagnant and running-water ecosystems (Ficetola et al., 2008; Goldberg et al., 2011; Hajibabaei et al., 2011). Thomsen et al. (2012) proposed a simple model that estimates population abundance based on animal body size and DNA degradation rate, for two amphibian species in a closed freshwater system and under controlled conditions. This study provides a first insight in estimating species abundance in freshwater systems. Although small animals can be detected in large amounts of closed water (e.g. $0.08 \mathrm{~g}$ fish per litre (Collins et al., 2012)), one important drawback is the rapid decrease in DNA concentration through time, especially in running-water systems (Dejean et al., 2011). In marine environments, water samples have mostly been used to study microbial communities (Zinger et al., 2012); however, the analysis of sediment samples has demonstrated the possibility of creating biodiversity inventories of eukaryotes at broad taxonomic scales (Pawlowski et al., 2011).

Soil DNA samples (sometimes called 'dirt' DNA) have been used by Andersen et al. (2012) as indicators of vertebrate diversity in zoological parks. However, this study focused on large vertebrates (elephants, ostriches, lions, giraffes, etc.) for which detection by conventional visual techniques is often more appropriate and environmental DNA sampling rarely necessary. The biomass of animal populations at a 
given site appeared to be one of the main drivers of DNA detection in soil samples (Andersen et al., 2012), suggesting that this approach would be considerably less effective for detecting smaller and/or less abundant species. Bienert et al. (2012), proposed a method for detecting the DNA of invertebrates from soil samples and identified nine co-occurring species of earthworms. This method appears sensitive enough to detect small quantities of extracellular DNA (possibly deriving from excreted fluids (Minamiya et al., 2011), faeces (Lefort et al., 2012) or exuviae (Lefort et al., 2012) of invertebrate species) and is therefore promising for biodiversity inventories. However, Bienert et al. (2012) did not discuss the possibility of estimating species abundance. One issue with their proposed method is that large quantities of DNA from one live specimen accidentally taken in one of their $0.5 \mathrm{~kg}$ soil cores could dominate the PCR process (Deagle \& Tollit, 2007) and mask the presence of other species, or at least result in a biased representation of species abundance. Such bias could be minimised by collecting several small soil cores and mixing them together to make a more representative sample (Taberlet et al., 2012).

Another example is DNA from regurgitation pellets that are produced by birds of prey and contain remains of prey that could not be digested. Because individual fragments (bones, feathers, fur, teeth etc.) can be easily isolated from pellets and analysed individually, molecular analysis of these do not involve mixed DNA samples and can be performed using Sanger sequencing (Taberlet \& Fumagalli, 1996). Such analyses have been performed to investigate the diversity and genetic variability in small mammals inhabiting the foraging areas of raptors (Hadly \& Tuinen, 2003) and barn owls (Poulakakis, 2005). Although this method can potentially inform biodiversity assessment of prey communities and shares similarities with the biodiversity capsule 
approach, it appears to be much more limited. Indeed, DNA from digestion pellets is only applicable to certain predatory birds species, and cannot be applied to soft-bodied prey. These methods are therefore much more limited and unlikely to produce as much insight as the analysis of faecal samples. 
Table 1: Non-exhaustive list of examples of prey communities and corresponding generalist predators that could be used in a biodiversity capsule approach.

*Faecal samples need to be independent (i.e. produced by different individual predators) for minimum estimates of prey abundance to be calculated.

Fig. 1: Prey DNA acquisition and deposition by generalist predators. A: Small and rare flying insects that are dispersed at low density over large areas and for which a generalist predator acquires and deposits their DNA in an aggregated manner and in an easily accessible location. B: Species inhabiting the open ocean or the deep sea, for which a generalist predator acquires and deposits their DNA on shore. C: Invertebrate communities inhabiting the soil, for which a generalist predator collects and deposits their DNA on the soil surface.

Fig. 2: Main differences between molecular diet analysis as commonly used in the current literature and the proposed approach of biodiversity capsules using faecal samples from generalist predators. Rationale, scope and strategies represent the 'why, when and how' of the two different approaches. 


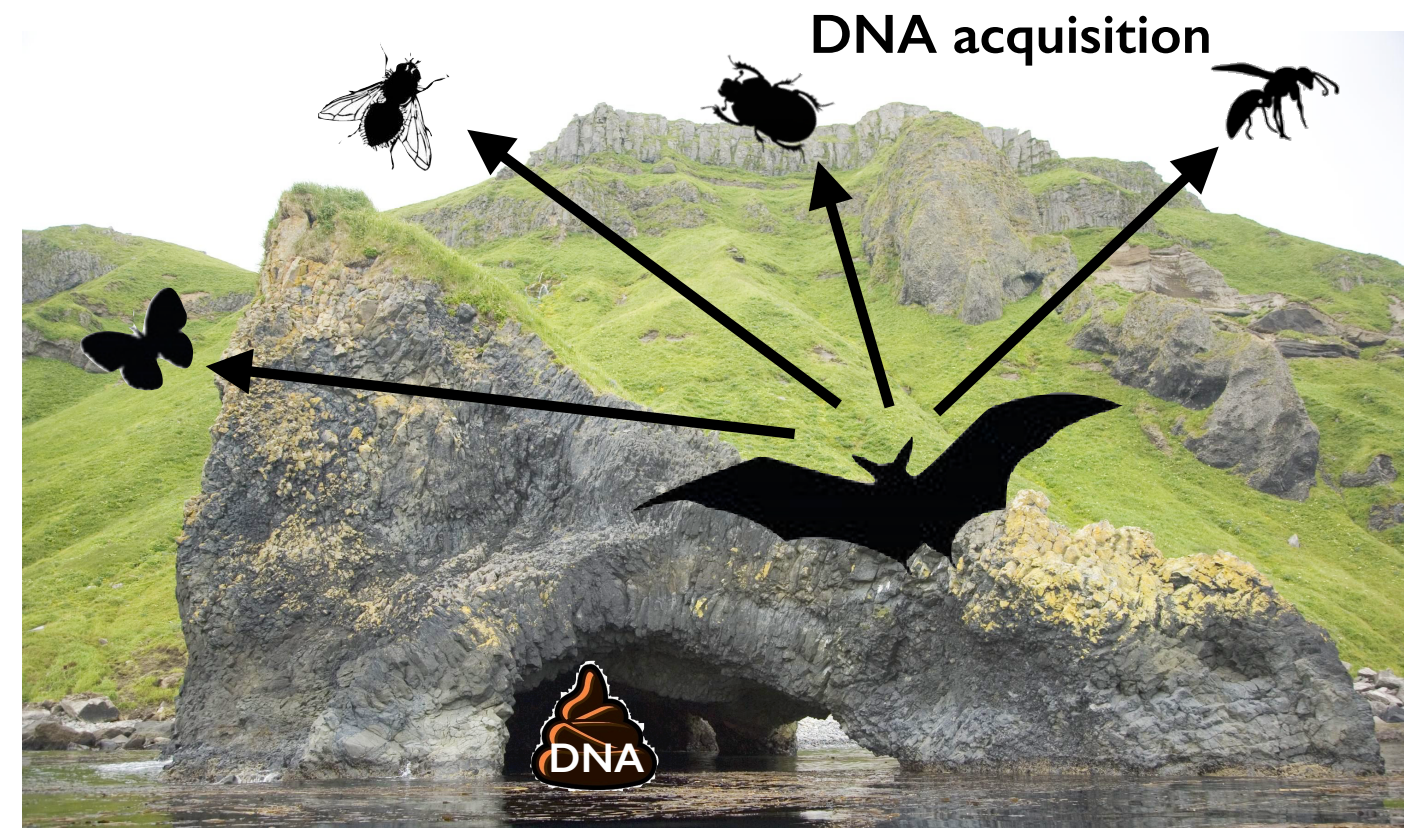

B

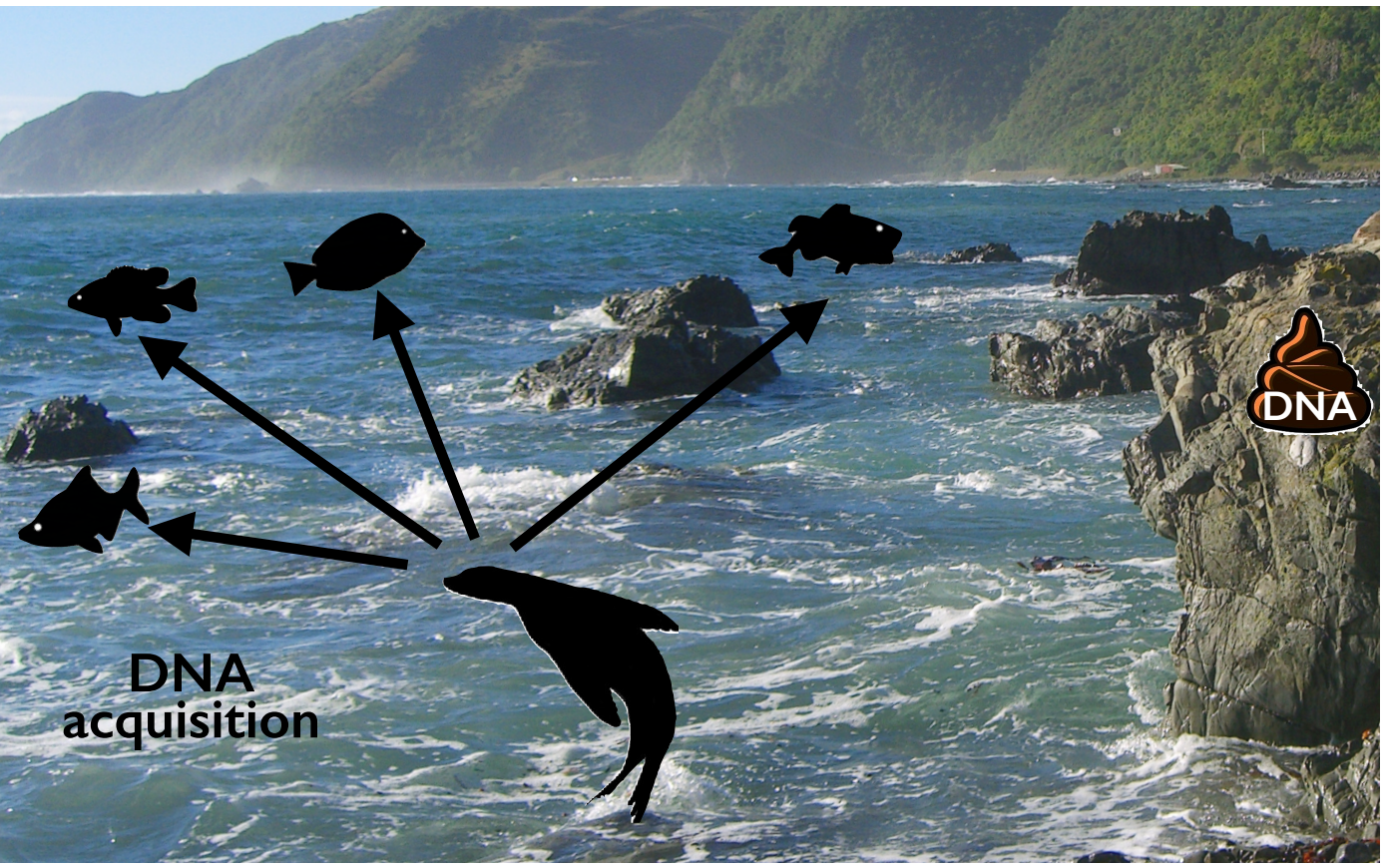

C

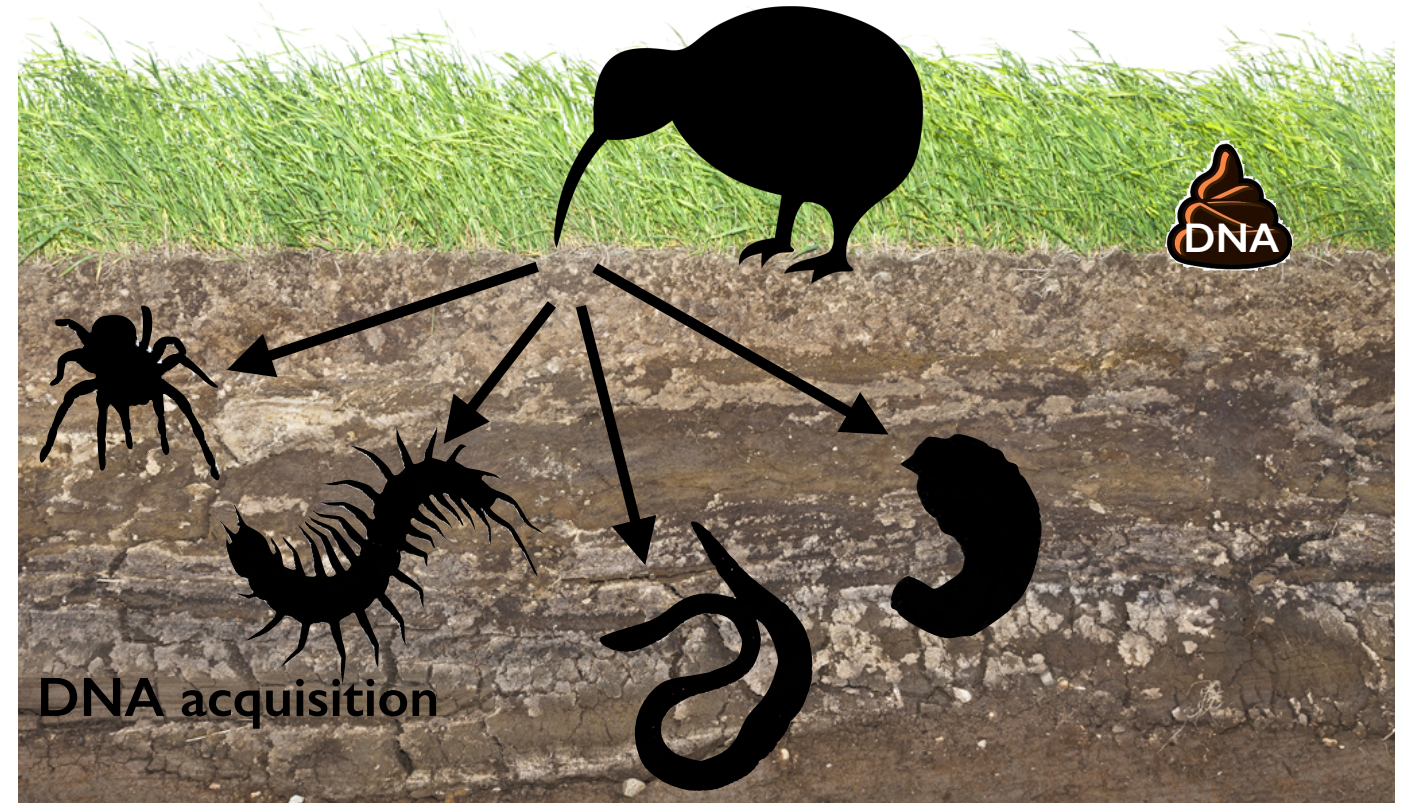




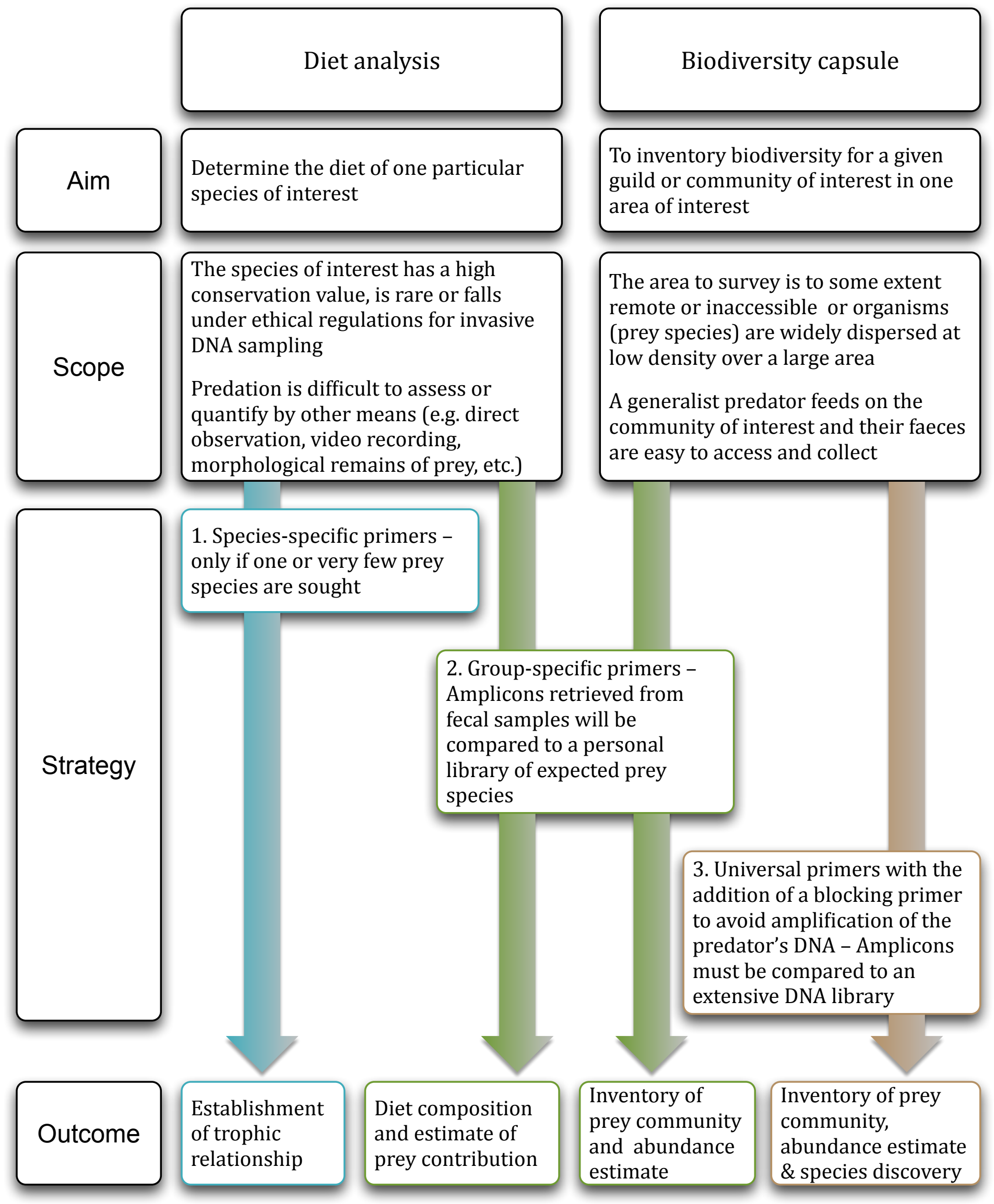

